\title{
SIFAT ORGANOLEPTIK BURGER AYAM DENGAN METODE MEMASAK YANG BERBEDA
}

\author{
Ratnasari Lumbong, R. M. Tinangon*, M. D. Rotinsulu, J. A. D. Kalele \\ Fakultas Peternakan Universitas Sam Ratulangi Manado, 95115
}

\begin{abstract}
ABSTRAK
Tujuan penelitian ini untuk mengetahui pengaruh metode memasak yang berbeda terhadap sifat organoleptik warna, aroma, tekstur, keempukan dan citarasa burger ayam. Penelitian ini menggunakan metode eksperimental dengan menggunakan Rancangan Acak Lengkap (RAL), dengan tiga perlakuan dan memakai skala hedonik dan 40 ulangan (Panelis) yang disusun sebagai berikut: R1=Mengukus, R2=Menggoreng, R3=Memanggang. Hasil penelitian menunjukkan bahwa mengukus, menggoreng dan memanggang memberikan pengaruh berbeda sangat nyata $(P<0,01)$ terhadap warna. Sebaliknya, terhadap tekstur dan keempukkan, perlakuan memberikan pengaruh berbeda nyata $(\mathrm{P}<0,05)$ dan pengaruh berbeda tidak nyata $(\mathrm{P}>0,05)$ terhadap aroma dan citarasa. Sehingga dapat disimpulkan bahwa burger ayam yang dimasak dengan menggunakan metode memanggang lebih disukai panelis.
\end{abstract}

Kata kunci: Burger Ayam, Mengukus, Menggoreng, Memanggang.

\section{ABSTRACT}

THE ORGANOLEPTIC CHARACTERISTIC OF CHICKEN BURGER WITH DIFFERENT COOKING METHODS. The objective of this study was to evaluate the effect of

*Korespondensi (corresponding Author) Email: rita.tinangon@gmail.com different cooking method on the characteristics of color, aroma, texture, tenderness and taste of chicken burger. Research was applied using completely randomized design with three treatments involving hedonic scale and forty replications using panelist as follows: Steaming (R1), Frying (R2), Baking (R3). Results showed that these three treatments affected significantly on color. $(\mathrm{P}<0.01)$, texture and tenderness $(\mathrm{P}<0.05)$. However, these treatments did not significantly affect on aroma and taste. Therefore, this research can be concluded that chicken burger cooked by baking method was mostly preferred by the panellist.

Keywords: Chicken Burger, Steaming, Frying, Baking.

\section{PENDAHULUAN}

Hamburger pertama kali muncul di Kota Hamburg, Jerman. Hamburger atau burger merupakan makanan sejenis sandwich, yang terdiri dari daging segar, digiling kemudian ditambahkan bumbubumbu, biasanya bentuknya agak gepeng setebal satu $\mathrm{cm}$. Produk ini telah lama dikenal dan disukai oleh masyarakat karena rasanya yang nikmat, gurih, dapat meningkatkan daya cerna protein, lemak dan mengandung protein. Pengolahan 
burger ayam dapat dilakukan dengan cara memasak, untuk membuat daging siap dikonsumsi. Tujuan memasak adalah menyatukan bahan, memperbaiki warna, meningkatkan juice, menonaktifkan mikroba serta membuat produk siap dikonsumsi. Memasak terdiri dari beberapa metode antaranya mengukus, menggoreng dan memanggang. Metode mengukus adalah teknik memasak dimana memasak bahan makanan dengan uap air mendidih pada suhu yang $100^{\circ} \mathrm{C}$. Metode menggoreng adalah memasak makanan dalam minyak. Dengan suhu yang biasa dipakai sekitar $175-190^{\circ} \mathrm{C}$ tergantung pada kekentalan dan tipe makanan yang digoreng. Metode memanggang adalah memasak makanan dengan menggunakan oven dimana suhu dan cara kerja diatur. Suhu yang biasa dipakai $150^{\circ} \mathrm{C}$. Metode memasak ini dapat diterapkan pada burger daging ayam. Penilaian organoleptik adalah penilaian mutu suatu produk dengan menggunakan indera manusia melalui syaraf sensorik meliputi sifat yang dapat dilihat, diraba, dicium dan dirasa. Penilaian organoleptik salah satu usaha penyatuan dan pemanfaatan kemampuan subjektif, cara ini menggunakan kemampuan pengamatan indera manusia (panelis). Dari latar belakang di atas telah dilakukan penelitian burger ayam terhadap sifat organoleptik dengan metode memasak yang berbeda.

\section{MATERI DAN METODE PENELITIAN}

Penelitian ini dilaksanakan sejak tanggal 16 Oktober sampai 17 November 2016 bertempat di Laboratorium Teknologi Hasil Ternak Fakultas Peternakan Universitas Sam Ratulangi Manado. Bahan yang digunakan adalah daging ayam pedaging sebanyak $1200 \mathrm{~g}$, minyak goreng 1 liter, tepung tapioka $150 \mathrm{~g}$, margarin $6 \mathrm{sm}$, susu skim $300 \mathrm{~g}$, telur ayam 6 butir, bawang merah $72 \mathrm{~g}$, bawang putih $72 \mathrm{~g}$, bawang bombai $105 \mathrm{~g}$, pala $1 \frac{1}{2} 2 \mathrm{st}$, lada $9 \mathrm{~g}$, garam $1 \frac{1}{2}$ sendok teh, gula $2 \frac{1}{4} \mathrm{~g}$, penyedap $24 \mathrm{~g}$, air mineral dan mentimun. Peralatan yang digunakan dalam pembuatan burger adalah timbangan analitik untuk menimbang bahan-bahan, kompor, pisau, talenan, belanga, wajan, oven listrik, water bath (thermologic), penggiling daging (maulinex), piring kertas, sendok, baskom, tissue, lembar kuisioner, pensil, penghapus dan penunjang lainnya. Penelitian ini menggunakan metode eksperimental dengan menggunakan Rancangan Acak Lengkap (Steel dan Torrie, 1991). Memakai skala hedonik dengan tiga perlakuan dan 40 ulangan (Panelis). Sebagai perlakuan disusun sebagai berikut 
R1 : Mengukus

R2 : Menggoreng

R3 : Memanggang

Variabel yang diamati adalah sifat organoleptik burger ayam yaitu : Warna, aroma, tekstur, keempukan dan citarasa. Menggunakan skala hedonik 1-7, dengan panelis tidak terlatih sebanyak 40 orang (Soekarto, 1985). Data yang diperoleh dianalisis dengan analisis keragaman (Analisis of Variance). Dan yang berbeda nyata dilanjutkan uji lanjut BNJ (Beda Nyata Jujur) (Steel and Torrie, 1991).

\section{HASIL DAN PEMBAHASAN}

Data hasil pengamatan pengaruh metode memasak yang berbeda terhadap warna, aroma, tekstur keempukan dan citarasa burger ayam, disajikan pada Tabel 1.

\section{Pengaruh Perlakuan Terhadap Warna Burger Ayam}

Tabel 1 memperlihatkan bahwa nilai rata-rata warna burger ayam tertinggi berada pada metode memanggang $(5,25$ artinya agak suka) sedangkan terendah pada metode mengukus (4,25 artinya netral). Hasil analisis sidik ragam menunjukkan bahwa metode memasak memberikan pengaruh berbeda sangat nyata $(\mathrm{P}<0,01)$ terhadap warna burger ayam. Hasil uji lanjut BNJ (Beda Nyata
Jujur), menunjukkan bahwa metode mengukus berbeda sangat nyata $(\mathrm{P}<0,01)$ dengan menggoreng dan memanggang, tetapi metode menggoreng berbeda tidak nyata $(\mathrm{P}>0,05)$ dengan memanggang. Warna burger ayam pada memanggang dan menggoreng disukai panelis. Warna burger ayam sebelum dimasak yaitu kemerahan sesudah dikukus putih kepucatan, digoreng kuning kecokelatan tua dan dipanggang kuning kecokelatan muda. Perubahan warna setelah digoreng diakibatkan terjadinya perubahan warna dari minyak goreng ke burger ayam. Setelah dipanggang terjadinya pindah panas secara konveksi dan konduksi sehingga lemak mencair memasak burger hingga kekuningan. Selain itu akibat pemanasan juga terjadi reaksi maillard untuk membentuk melanoit yaitu zat warna burger ayam jadi kuning kecokelatan. Hal ini sejalan dengan pendapat (Winarno, 1999) bahwa reaksi maillard merupakan reaksi pencokelatan non enzimatis antara gula pereduksi dan gugus amin bebas dari asam amino atau protein, sehingga mengakibatkan warna pada bahan pangan menjadi cokelat. Selanjutnya Zahra et al. (2013) menambahkan bahwa bahan pangan yang dimasak bukan saja menjadi matang, tetapi karena penggunaan suhu yang cukup tinggi sehingga menjadi warna cokelat tua pada bahan pangan. 
Tabel 1. Rata-Rata Pengaruh Perlakuan Terhadap Burger Ayam Dengan Metode Memasak Yang Berbeda.

\begin{tabular}{cccc}
\hline \multirow{2}{*}{ Variabel } & \multicolumn{3}{c}{ Perlakuan Metode Memasak } \\
\cline { 2 - 4 } & Mengukus & Menggoreng & Memanggang \\
\hline Warna & $4,25^{\mathrm{a}}$ & $5,10^{\mathrm{b}}$ & $5,25^{\mathrm{b}}$ \\
Aroma & $5,20^{\mathrm{a}}$ & $5,48^{\mathrm{a}}$ & $5,38^{\mathrm{a}}$ \\
Tekstur & $4,95^{\mathrm{b}}$ & $4,43^{\mathrm{a}}$ & $5,20^{\mathrm{b}}$ \\
Keempukan & $5,15^{\mathrm{b}}$ & $4,33^{\mathrm{a}}$ & $5,00^{\mathrm{b}}$ \\
Citarasa & $5,38^{\mathrm{a}}$ & $5,30^{\mathrm{a}}$ & $5,68^{\mathrm{a}}$ \\
\hline
\end{tabular}

Keterangan : Superskrip berbeda pada baris yang sama artinya berbeda nyata $(\mathrm{P}<0,05)$

\section{Pengaruh Perlakuan Terhadap Aroma Burger Ayam}

Tabel 1 memperlihatkan bahwa nilai rata-rata aroma burger ayam tertinggi pada metode menggoreng (5,48 artinya agak suka) dan terendah pada mengukus (4,90 artinya agak suka). Hasil analisis sidik ragam menunjukkan bahwa metode memasak memberikan pengaruh berbeda tidak nyata $(\mathrm{P}>0,05)$ terhadap aroma burger ayam. Pengolahan burger dari ketiga metode memasak belum terjadi perbedaan hal ini karena bahan pangan mengandung karbohidrat dan protein jika dipanaskan akan mengalami pencoklatan non enzimatis, apabila bahan tersebut dipanaskan (reaksi maillard) akan dapat menghasilkan bau enak. Komponen karbonil yang terbentuk selama proses pemasakan dapat bereaksi dengan asam amino, amin, dan protein menghasilkan flavor yang diinginkan (Negroni et al., 2001). Aroma yang timbul dalam proses pemasakan sebagian merupakan aroma dari senyawa-senyawa kimia yang ikut menguap bersama air bebas yang terkandung dalam bahan pangan tersebut. Manusia dapat mencium bau yang keluar dari makanan kerena adanya sel-sel epitel alfaktori dari bagian dinding atas rongga hidung yang peka terhadap komponen bau (Soekarto, 1985).

\section{Pengaruh Perlakuan Terhadap Tekstur Burger Ayam}

Tabel 1 memperlihatkan bahwa nilai rata-rata tekstur burger ayam tertinggi pada metode memanggang (5,20 artinya agak suka) dan terendah pada menggoreng (4,95 artinya agak suka). Hasil analisis sidik ragam menunjukkan bahwa metode memasak yang berbeda memberikan pengaruh nyata $(\mathrm{P}<0,05)$ terhadap tekstur burger ayam. Hasil uji lanjut BNJ (Beda Nyata Jujur), menunjukkan bahwa metode menggoreng berbeda nyata $(\mathrm{P}<0,05)$ 
dengan mengukus dan memanggang, selanjutnya metode mengukus berbeda tidak nyata $(\mathrm{P}>0,05)$ dengan memanggang. Tekstur pada metode memanggang dan mengukus disukai panelis karena pada metode mengukus terjadi pemasakan dengan uapan air mendidih akibatnya protein ikut terlarut sehingga menghasilkan tekstur yang disukai. Hal ini didukung Ikram dan Ismail, (2004) menyatakan bahwa pengukusan menyebabkan protein terlarut dalam media pengukusan sehigga bahan makanan menghasilkan tekstur yang baik. Sedangkan pada metode memanggang energi panas terjadi secara konduksi dan konveksi, sehingga kandungan bahan pangan terlarut terutama protein. Hal ini sejalan dengan penelitian Nikmaram et al. (2011) bahwa pemanggangan dengan lama dan suhu tertentu memberikan suatu hasil bahwa nilai tekstur daging berbeda nyata $(\mathrm{P}<0,05)$ artinya nilai teksturnya baik. Ditambahkan juga hasil penelitian perlakuan lama pemanggangan dalam microwave pada daging steak ayam memberikan pengaruh yang sangat nyata $(\mathrm{P}<0,01)$ terhadap tekstur (Nazhar et al., 2012).

\section{Pengaruh Perlakuan Terhadap Keempukan Burger Ayam}

Tabel 1 memperlihatkan bahwa nilai rata-rata keempukan burger ayam tertinggi pada metode mengukus $(5,15$ artinya agak suka) dan terendah pada menggoreng (4,33 artinya netral). Hasil analisis sidik ragam menunjukkan bahwa metode memasak yang berbeda memberikan pengaruh nyata $(\mathrm{P}<0,05)$ terhadap keempukan burger ayam. Hasil uji lanjut BNJ (beda nyata jujur), menunjukkan bahwa metode menggoreng berbeda nyata $(\mathrm{P}<0,05)$ dengan memanggang dan mengukus, tetapi metode memanggang berbeda tidak nyata $(\mathrm{P}>0,05)$ dengan mengukus. Keempukan pada metode mengukus dan metode memanggang disukai hal ini karena terjadi perubahan stuktur protein terutama aktin dan miosin pada saat bahan pangan dimasak sehingga menghasilkan keempukan yang baik. Hal ini didukung (Bouton et al., 1971 dan Soeparno, 2005) menyatakan tiga komponen yang menentukan keempukan daging antara lain struktur miofibrilar (miosin, aktin dan tropomiosin) dan status kontraksi otot, kandungan jaringan ikat dan ikatan silangnya, dan daya ikat air oleh protein daging serta jus daging. Vural (2003) mengemukakan bahwa lemak memiliki arti penting dalam produk olahan daging karena berpengaruh terhadap keempukan dan juiciness. Selanjutnya ditambahkan (Sudrajat, 2003) bahwa perlakuan pemasakan akan mempengaruhi kualitas daging, karena panas akan menguapkan air, mendegradasi protein, 
dekomposisi asam amino dan mengakibatkan jaringan ikat mengalami pengembangan sehingga akan menambah keempukan dan kesan jus daging. Ditambahkan Sundari et al. (2015) bahwa proses pengolahan bahan pangan yang dapat mengakibatkan penurunan kandungan gizi yang sangat signifikan karena menggunakan suhu lebih dari $160^{\circ} \mathrm{C}$, sehingga protein mengalami kerusakan.

\section{Pengaruh Perlakuan Terhadap Citarasa Burger Ayam}

Tabel 1 memperlihatkan bahwa nilai rata-rata citarasa burger ayam tertinggi pada metode memanggang (5,68 artinya suka) dan terendah pada menggoreng $(5,30$ artinya agak suka). Hasil analisis sidik ragam menunjukkan bahwa perlakuan metode memasak yang berbeda memberikan pengaruh berbeda tidak nyata $(\mathrm{P}>0,05)$ terhadap citarasa burger ayam. Citarasa merupakan gabungan antara rasa dan aroma. Citarasa pada metode mengukus, menggoreng, dan memanggang disukai panelis hal ini karena pada saat memasak terjadi peningkatan citarasa yang disebabkan oleh adanya degradasi atau penguraian senyawa makromolekul daging broiler. Penilaian citarasa dilihat dari tekstur dan penampilan warna (Hughes et al., 1997). Selanjutnya De Souza et al. (2005) dalam Tinangon et al. (2014) menyatakan bahwa penggunaan rempah pada umumnya akan meningkatkan aroma dan citarasa pada pangan olahan.

\section{KESIMPULAN}

Berdasarkan analisis data dan pembahasan untuk semua variabel dapat disimpulkan bahwa burger ayam yang dimasak dengan menggunakan metode memanggang lebih disukai panelis.

\section{DAFTAR PUSTAKA}

Bouton, P. E., Harris and Shorthose. 1971. Effect of ultimate $\mathrm{pH}$ upon the water holding capacity and tenderness of mutton. Journal Food Sci. 36 : 435439.

Hughes E., S. Cofrades and D. J. Troy. 1997. Effects of fat level, oat fiber and carrageenan on frankfurters formulated with 5, 12 and $30 \%$ fat. Journal. Meat Sci., 45(3): 273-2810.

Ikram E. H. K, and A. Ismail. 2004. Effects of cooking practices (boiling and frying) on the protein and amino acids contents of four selected fishes. Journal of Food Sciencesand Nutrition 34(2): 54-59.

Nazhar, V.B.R., D. Rosyidi, dan A. S. Widati. 2012. Pengaruh lama pemanggangan dalam microwave terhadap kualitas fisik steak daging ayam. Universitas Brawijaya. Jurnal Ilmu dan Teknologi Hasil Ternak.Hal 6-11 Vol. 7, No. 1.

Negroni, M., A. D'Agustina, and A. Arnoldi. 2001. Effects of olive oil, 
canola, and sunflower oils on the formation of volatiles from the maillard reaction of lysinewith xylose and glucose. Journal Agric Food Chem 49:439-45.

Nikmaram. P., M.S. Yarmand, Z. Emamjomeh and H. K. Darehabi 2011. The effect of cooking methods on textural and microstructure properties of veal muscle (longissimus dorsi). Journal Global Veterinaria 6 (2): 201-207

Soekarto, S.T. 1985. Penilaian Organoleptik untuk Industri Pangan dan Hasil Pertanian. Bhratara Karya Akasara. Jakarta.

Soeparno, 2005. Ilmu dan Teknologi Daging. Cet 4, Gadja Mada University Press. Yogyakarta.

Steel, R. G. D. and J.H. Torrie. 1991. Prinsip dan Prosedur Statistika, Suatu Pendekatan Biometrik. PT Gramedia Pustaka Utama. Jakarta.

Sudrajat, A. 2015. Pengaruh Temperatur Lama Pemasakan Terhadap Karakteristik Fisik dan Organoleptik Daging Ayam Broiler. Skripsi. Fakultas Peternakan, Universitas Sebelas Maret, Surakarta.

Sundari, D., Almasyhuri, dan Lamid. 2015. Effect of cooking process of composition nutritional substances some food ingredients protein source. Journal Media Litbangkes 25(4): 235 -242 .

Tinangon, R., D. Rosyidi, L. Radiati and Purwadi. 2014. The influence of clove addition onphysico-chemical and organoleptical characteristics of burger meat. Brawijaya University, Malang. Scholars Journal of
Engineering and Technology, 2014; 2(6B):886-889.

Vural, H. 2003. Effect of replacing beef fat and tail fat with interesterified plant oil on quality characteristic of turkish semi-dry fermented sausages. Eur. Journal Food Res. Technol. Vol 217:100-10.

Winarno, F. G. 1997. Kimia Pangan dan Gizi. PT Gramedia Pustaka Utama, Jakarta.

Zahra, S. L., S.B. Dwiloka dan Mulyani. 2013. Pengaruh penggunaan minyak goreng berulang terhadap perubahan nilai gizi dan mutu hedonik pada ayam goreng. Universitas diponegoro. Semarang. Animal Agriculture Journal, Vol. 2. No. 1, 2013, P 253 - 260 Online At

Http://EjournalS1.Undip.Ac.Id/Index.Ph p/Aaj 